\title{
Identification of propionibacteria isolated from brown spots of Swiss hard and semi-hard cheeses
}

\author{
Denise Fessler ${ }^{\mathrm{a}, \mathrm{b}}$, Michael G. Casey ${ }^{\mathrm{b} *}$, Zdenko Puhan $^{\mathrm{a}}$ \\ ${ }^{a}$ Laboratory of Dairy Science, Swiss Federal Institute of Technology, Zurich, Switzerland \\ ${ }^{b}$ Federal Dairy Research Institute, 3003 Bern, Switzerland
}

(Received 22 September 1997; accepted 8 September 1998)

\begin{abstract}
One hundred and thirty-five propionibacteria isolated from brown spots of Appenzell, Emmental, Raclette and Sbrinz cheese were analyzed by random amplified polymorphic deoxyribonucleic acid (RAPD) and protein profiling. Both Propionibacterium freudenreichii subsp. shermanii and $P$. freudenreichii subsp. freudenreichii seem to be involved in the formation of brown spots in all these cheeses. In all Appenzell cheeses, in addition to $P$. freudenreichii, slow-growing P. acidipropionici and $P$. jensenii strains, which are known to cause brown spots, were found. A high proportion of unknown bacteria were noted in the brown spots of Raclette cheese. None of the isolated strains from Appenzell, Raclette and Sbrinz came from the commercial propionibacteria used in cheese production. Only one of the strains isolated was found in raw milk obtained from the same region where the cheese was produced. (C) Inra/Elsevier, Paris
\end{abstract}

\section{Propionibacterium / cheese / electrophoresis / PCR}

Résumé - Identification des bactéries propioniques dans les points bruns des fromages suisses à pâte dure et mi-dure. Cent trente cinq bactéries propioniques isolées des points bruns des fromages emmental, sbrinz, appenzell et raclette ont été analysées par RAPD et par SDS-PAGE de leurs protéines. Diverses souches des deux sous-espèces de $P$. freudenreichii, shermanii et freudenreichii, semblent jouer un rôle dans la formation des points bruns dans ces fromages. Non seulement des souches de $P$. freudenreichii mais également de souches à croissance lente de $P$. acidipropionici et $P$. jensenii, qui sont connues pour favoriser la formation de points bruns, ont été trouvées dans tous les fromages d'appenzell. Une proportion importante de bactéries inconnues ont été trouvées dans les points bruns des fromages à raclette. Aucune des souches isolées des fromages sbrinz, appenzell et raclette ne provenait des cultures commerciales fournies par la station fédérale de recherches laitières suisse. Parmi les souches isolées, une seule a aussi été trouvée dans le lait cru obtenu de la region où le fromage avait été produit. (C) Inra/Elsevier, Paris

\section{bactérie propionique / fromage / électrophorèse / PCR}

\footnotetext{
* Correspondence and reprints. michael.casey@mbox.fam.admin.ch
} 


\section{INTRODUCTION}

Two main defects are caused by propionibacteria in cheese. The most common defect is the so-called 'split defect' [8] or 'late fermentation' in Emmental and other hard and semi-hard cheeses produced from raw milk. The height of the cheese is increased and fissures or cracks may appear in the cheese while it is being ripened in the cold cellar at approximately $10^{\circ} \mathrm{C}[9,11]$. Therefore, propionibacteria able to grow and produce $\mathrm{CO}_{2}$ at low temperature are thought to be responsible for the split defect [7].

The other cheese defect called "brown spot' has been described in Swiss hard and semi-hard cheeses made from raw milk [2] and seems to be caused by the formation of large colonies of $P$. freudenreichii. The development of brown spots in Emmental cheese can be suppressed by adding increased amounts of propionibacteria to the milk. In other hard or semi-hard cheeses such as Tilsit, Sbrinz and Appenzell, where propionibacteria are not intentionally added to milk for cheese-making, and where the growth of these bacteria is undesirable, the development of brown spots can be influenced by some technological parameters such as more intensive salting or increased levels of copper or lactate of young cheese. Also, the addition of facultative heterofermentative lactobacilli can partially prevent the occurrence of brown spots [13]. Complete inhibition, however, requires salt concentrations of $15-20 \mathrm{~g} \cdot \mathrm{kg}^{-1}$ cheese [10], which seriously diminishes the sensorial properties of the product. Brown spots usually appear after 3 months of ripening, first in the peripheral area then in the whole cheese loaf. Brown-spotted cheese cannot be sold as a premium grade product, because consumers are unsure about the origin of brown spots and find them unappetising [13].

In the present study propionibacteria isolated from brown spots of various types of cheeses were analyzed in order to obtain more knowledge about the species and strains of Propionibacterium involved in this defect.

\section{MATERIALS AND METHODS}

\subsection{Propionibacterial strains and culture conditions}

Reference strains were received from the American Type Culture Collection (ATCC), and the Deutsche Sammlung von Mikroorganismen und Zellkulturen GmbH (DSM). Strains from the P-culture, which is a mixture of six strains of propionic acid bacteria, used for Emmental cheese manufacture all over Switzerland for many decades, and Prop 96, a mixture of two strains, used in Switzerland for Emmental manufacture since 1996, were obtained from the Federal Dairy Research Institute, Switzerland.

Bacterial strains were isolated from brown spots of Appenzell (6 months old), Emmental ( 5 months old), Raclette ( 2 months old) and Sbrinz (6-30 months old) cheeses. Observations of brown spots in cheese with a raster electron microscope showed that bacteria were concentrated in the brown spot and that the surrounding area was devoid of any microorganisms (results not shown). The cheeses were cut with a sterile knife and ten brown spots per cheese were removed with a sterile scalpel. Care was taken to avoid contaminating the sample with cheese from the surrounding area. The samples were inoculated into YEL $\left(24 \mathrm{~mL} \cdot \mathrm{L}^{-1}\right.$ sodium lactate [50\% v/v], $30 \mathrm{~g} \cdot \mathrm{L}^{-1}$ casein peptone and $30 \mathrm{~g} \cdot \mathrm{L}^{-1}$ yeast extract, $\mathrm{pH} 6.8$ ) broth for 5 to $7 \mathrm{~d}$ at $30^{\circ} \mathrm{C}$ and then plated out on YELA (YEL containing $15 \mathrm{~g} \cdot \mathrm{L}^{-1}$ agar). Only bacterial colonies that differed in appearance from one another were chosen. The appearance of each colony was noted, their morphology under the microscope and the presence of catalase tested with $3 \%(\mathrm{v} / \mathrm{v}) \mathrm{H}_{2} \mathrm{O}_{2}$. The strains were then re-streaked three times on YELA for $10 \mathrm{~d}$ at $30^{\circ} \mathrm{C}$ under anaerobic conditions to purify them. Strains were subsequently grown in YEL broth for 5 to $7 \mathrm{~d}$ at $30^{\circ} \mathrm{C}$.

\subsection{Protein profiles and RAPD}

Analyses of protein profiles and randomly amplified polymorphic deoxyribonucleic acid (RAPD) were performed as described previously [6]. Previous researchers $[3-5,12]$ using sodium dodecyl sulphate-polyacrylamide gel electrophoresis (SDS-PAGE) reported a reproducibility of this technique at the $92-98 \%$, $95.9 \pm 1.7 \%$ and $93-97 \%$ level, respectively. Reproducibility of RAPD was described by Fessler et al. [6]. 


\subsection{Differentiation of the subspecies of $P$. freudenreichii}

Analyses were performed as described by Fessler et al. [6].

\subsection{Growth of propionibacteria}

MF95C medium was prepared according to Jimeno (personal communication): $1.4 \mathrm{~mL}$ $\mathrm{K}_{2} \mathrm{HPO}_{4}\left(1 \mathrm{~mol} \cdot \mathrm{L}^{-1}\right), 3.5 \mathrm{~mL}$ DL-lactic acid $(88 \%), 1 \mathrm{~mL}$ citric acid $\left(1 \mathrm{~mol} \cdot \mathrm{L}^{-1}\right)$, and $0.37 \mathrm{~g}$ $\mathrm{CaCO}_{3}$ was made up to approximately $20 \mathrm{~mL}$ with distilled water; $5.2 \mathrm{~mL} \mathrm{KOH}\left(1 \mathrm{~mol} \cdot \mathrm{L}^{-1}\right)$ was added and the $\mathrm{pH}$ adjusted to 5.0 with $\mathrm{NaOH}$ $\left(5 \mathrm{~mol} \cdot \mathrm{L}^{-1}\right) ; 2 \mathrm{~g}$ tryptone and $1 \mathrm{~g}$ yeast extract were added and the $\mathrm{pH}$ adjusted to 5.6 with $\mathrm{NaOH}\left(5 \mathrm{~mol} \cdot \mathrm{L}^{-1}\right) ; 2 \mathrm{~mL} \mathrm{MgSO}_{4}\left(1 \mathrm{~mol} \cdot \mathrm{L}^{-1}\right)$, $0.17 \mathrm{~mL} \mathrm{ZnCl},\left(0.1 \mathrm{~mol} \cdot \mathrm{L}^{-1}\right)$ and $58 \mu \mathrm{L} \mathrm{CuCl}_{2}$ $\left(0.1 \mathrm{~mol} \cdot \mathrm{L}^{-1}\right)$ was added and the $\mathrm{pH}$ adjusted with $\mathrm{NaOH}\left(5 \mathrm{~mol} \cdot \mathrm{L}^{-1}\right)$. The content of sodium was calculated and adjusted to $30 \mathrm{mmol}$ with $\mathrm{NaCl}$. The volume was adjusted to $100 \mathrm{~mL}$ and the solution sterilized by filtration.

Growth of propionibacteria was followed on microtiter plates: $17 \mu \mathrm{L}$ of liquid bacterial culture was mixed with $170 \mu \mathrm{L}$ MF95C in each well of the plate, so that the initial absorbance at $650 \mathrm{~nm}$ was approximately 0.2 . The plates were incubated in an anaerobic jar at $30^{\circ} \mathrm{C}$ and the $\mathrm{A}_{650}$ measured in an Uvikon photometer once a day for $13 \mathrm{~d}$. The repeatability for growth of the $\mathrm{P}$ mixed culture was $94 \%$.

\section{RESULTS AND DISCUSSION}

The results of the analysis of all the strains isolated from the brown spots in cheese are summarized in table $I$.

\subsection{Emmental}

Only one Emmental cheese with brown spots was analyzed, because this defect has become rarer in recent years due to the use of larger amounts of the P-culture. The 10 isolates from the brown spots from this cheese were classified by protein analysis as $P$. freudenreichii. Nine of these strains belonged to $P$. fr 410 ) in the P-culture. The six other strains were wild strains. Figure 1 shows RAPD profiles with primer DF4 of nine different strains isolated from Emmental cheese. None of the wild strains were identical to any $P$. freudenreichii strains isolated from raw milk of the Bern region, where this Emmental was produced [6]. However, this is not surprising since it was very rare to find the same strain of Propionibacterium in two different milks [6]. According to Baer et al. [2], brown spots occur in Emmental cheese when the number of propionibacteria added to the raw milk is too low. The cheese manufacturer obviously added the P-culture to the milk, since

Table I. Identification of bacterial strains isolated from brown spots of cheese.

Tableau I. Identification de souches bactériennes isolées des points bruns du fromage.

\begin{tabular}{|c|c|c|c|c|}
\hline Type of cheese & $\begin{array}{l}\text { No. of cheeses } \\
\text { analyzed }\end{array}$ & $\begin{array}{l}\text { No. of strains } \\
\text { isolated }\end{array}$ & Species & $\begin{array}{l}\text { No. of propionibacteria } \\
\text { with different RAPD profiles }\end{array}$ \\
\hline
\end{tabular}

\begin{tabular}{lcccc}
\hline Appenzell & 4 & 43 & $\begin{array}{c}8 \text { P.a., 2 P.j., } \\
10 \text { P.f.f., 22 P.f.s., } \\
1 \text { n.i. }\end{array}$ & 23 \\
Emmental & 1 & 10 & 9 P.f.f., 1 P.f.s. & 7 \\
Raclette & 1 & 10 & 2 P.f.f., 8 n.i. & 2 \\
Sbrinz & 8 & 72 & 17 P.f.f., 53 P.f.s., & 37 \\
\hline
\end{tabular}

P.a.: P. acidipropionici; P.j.: P. jensenii; P.f.f.: P. freudenreichii subsp. freudenreichii; P.f.s.: P. freudenreichii subsp. shermanii; n.i.: not identified.

n.i. : non identifié. 


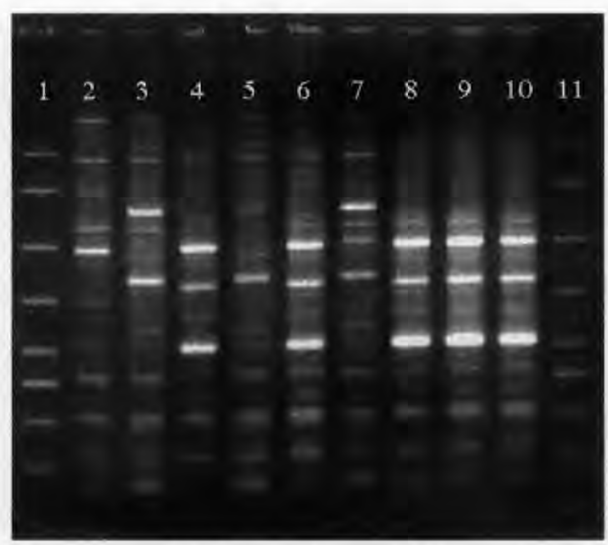

Figure 1. RAPD profiles obtained with primer DF4 of $P$. freudenreichii strains isolated from the brown spots of Emmental cheese. 2, 3, 4, 5, $6,7,8,9,10=P$. freudenreichii strains; $1,11=50-2000 \mathrm{bp}$ ladder.

Figure 1. Profils de RAPD obtenus avec primer DF4 de souches de $P$. freudenreichii isolées de points bruns d'emmental $(2,3,4,5,6,7,8,9$, $10=$ souches de $P$. freudenreichii ; $1,11=$ 50-2000 bp ladder).

four strains from it were found to be similar to one strain (P1410) in the P-culture. Nevertheless, the proliferation of wild strains of propionibacteria in this cheese indicates that either they grew more rapidly than those of the P-culture or that the amount of P-culture added was too low.

\subsection{Sbrinz}

Of the total of 72 strains isolated from the brown spots of eight Sbrinz cheeses, two strains were identified by protein profile analysis as not being propionibacteria and all other strains were classified as $P$. freudenreichii. Of the $70 P$. freudenreichii strains, 17 were $P$. freudenreichii subsp. freudenreichii and the remaining 53 strains were $P$. freudenreichii subsp, shermanii. Of the eight cheeses, seven harboured $P$. freudenreichii subsp freudenreichii strains. It is possible, that of the four dairy propionibacteria species only $P$. freudenreichii strains are able to survive the scalding temperature $\left(56-58{ }^{\circ} \mathrm{C}\right)$ during manufacture of Sbrinz and grow during ripening at $13{ }^{\circ} \mathrm{C}$.

It was not possible to detect a specific strain common to all Sbrinz cheeses with brown spots by RAPD with SK2 and DF4. Among the 70 isolates of propionibacteria, 37 different strains could be identified. One strain was found to occur in two separate Sbrinz cheeses. Thus, it can be concluded that many different $P$. freudenreichii strains seem to have the capacity to produce brown spots in Sbrinz cheese. Figure 2 shows RAPD profiles of some of the different strains isolated from two Sbrinz cheeses.

Of all the $P$. freudenreichii strains isolated from brown spots of Sbrinz, only one strain was found to be identical to a strain isolated from the raw milk of central Switzerland where Sbrinz cheese is produced [6]. None of the strains originating from Sbrinz cheese was identical to any of the strains of P-culture and Prop 96.

\subsection{Appenzell}

Forty-three strains were isolated from four Appenzell cheeses with brown spots. Protein profiles showed, that one of the strains was not a Propionibacterium. Eight strains were $P$. acidipropionici, two $P$. jensenii and the remainder $P$. freudenreichii. Of the $32 P$. freudenreichii strains, 22 were able to ferment lactose and were thus classified as $P$. freudenreichii subsp. shermanii; the remaining ten were classified as $P$. freudenreichii subsp. freudenreichii.

The brown spots of the four Appenzell cheeses all contained $P$. freudenreichii and either strains of $P$. acidipropionici or P. jensenii or both. These three Propionibacterium species are able to survive the scalding temperature $\left(44^{\circ} \mathrm{C}\right)$ used in the manufacture of Appenzell cheese. The growth of the eight $P$. acidipropionici strains and of one of the $P$. jensenii strains in medium MF95C was considerably slower than that of the $P$. freudenreichii strains. The slow-growing strains of $P$. jensenii and 


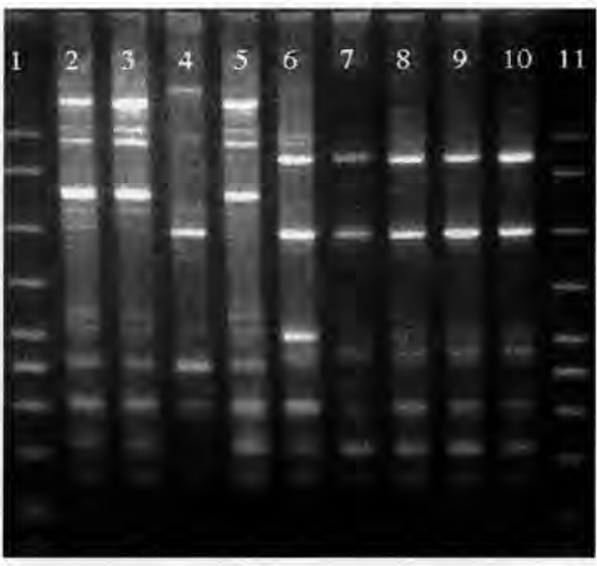

Figure 2. RAPD profiles obtained with primer DF4 of $P$. freudenreichii strains isolated from the brown spots of Sbrinz cheese. 2, 3, 4, $5,6=$ strains from cheese number $4 ; 7,8,9$, $10=$ strains from cheese number $3 ; 1,11=$ 50-2 000 bp ladder.

Figure 2. Profils de RAPD obtenus avec primer DF4 de souches de $P$. freudenreichii isolées de points bruns de Sbrinz (2, 3, 4, 5, 6 = souches de fromage numéro $4 ; 7,8,9,10=$ souches de fromage numéro $3 ; 1,11=50-2000$ bp ladder).

$P$. acidipropionici were found in all four Appenzell cheeses. Although Park et al. [9] showed that not all $P$. acidipropionici and $P$. jensenii strains grew at low temperatures $\left(12.8^{\circ} \mathrm{C}\right)$, the ripening temperature of $14-16^{\circ} \mathrm{C}$ for Appenzell cheese apparently does not affect the growth of the strains isolated in the present study. A previous study [1] showed, that a slow propionic acid fermentation occurred in Emmental cheese to which $P$. acidipropionici was added, which led to the formation of brown spots. According to the same authors, the slow propionic fermentation increased the risk of formation of brown spots. Consequently, brown spot formation in Appenzell cheese is probably caused by $P$. freudenreichii as well as by $P$. jensenii and $P$. acidipropionici.

RAPD profiles of the $P$. freudenreichii strains obtained with both primers SK2 and DF4 showed the presence of 20 different strains at the $88 \%$ similarity level. None of the strains occurred in two different Appenzell cheeses showing brown spots. In addition, none of the strains were similar to the eight $P$. freudenreichii strains present in the P- and Prop 96 cultures or to any of the strains isolated from raw milk of the northeast of Switzerland where Appenzell is produced [6]. The two strains of $P$. jensenii differed from one another. With the primer used it was not possible to distinguish between the different strains of $P$. acidipropionici. Figure 3 shows RAPD profiles of some of the different strains isolated from two Appenzell cheeses.

\subsection{Raclette}

From the brown spots of one Raclette cheese, ten strains were isolated and analyzed. Eight strains were not propionibacteria, and the remaining two were classified as $P$. freudenreichii subsp. freudenreichii according to protein profiles and growth on MGM with lactose. Both strains showed different profiles with primers SK2 and DF4. The high proportion of unknown bacteria in the brown spots of this Raclette cheese is notable, but the evidence is not sufficient to draw conclusions as to whether propionibacteria are involved in producing brown spots.

\subsection{Conclusion}

Various strains of $P$. freudenreichii subsp. freudenreichii and $P$. freudenreichii subsp. shermanii seem to be responsible for the formation of brown spots in Emmental and Sbrinz. In the brown spots of the single Raclette cheese analyzed, a number of nonpropionibacteria were found in addition to the $P$. freudenreichii strains. Their influence on the formation of brown spots in this cheese type is unclear. In the brown spots of Appenzell cheese, slow-growing strains of $P$. acidipropionici and $P$. jensenii have been found in addition to $P$. freudenreichii strains. It is known that the slow fermentation of these strains increases the risk of brown spot formation [1]. None of the $P$. freudenreichii 


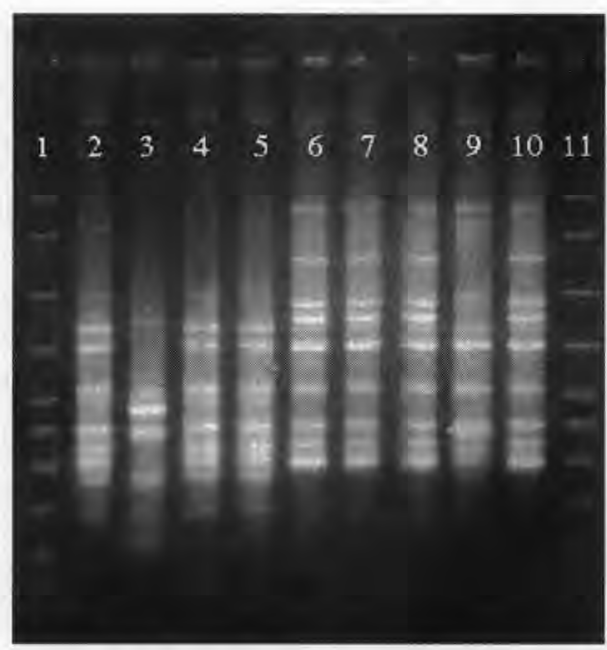

Figure 3. RAPD profiles obtained with primer SK2 of Propionibacterium strains isolated from the brown spots of Appenzell cheese. 2, 4, $5=$ $P$. freudenreichii strains from cheese number 3 ; $3=P$. jensenii strain from cheese number $3 ; 6,7$, $8,9,10=P$. freudenreichii strains from cheese number $2 ; 1,11=50-2000$ bp ladder.

Figure 3. Profils de RAPD obtenus avec primer SK2 de souches de Propionibacterium isolées de points bruns d'appenzell $(2,4,5=$ souches de $P$. freudenreichii de fromage numéro 3 ; $3=$ souches de $P$. jensenii de fromage numéro $3 ; 6,7,8,9,10=$ souches de $P$. freudenreichii de fromage numéro $2 ; 1,11=50-2000 \mathrm{bp}$ ladder).

strains isolated from Appenzell, Sbrinz and Raclette was identical to any strains of the commercial propionibacterial cultures used in the manufacture of Emmental cheese in Switzerland. Only one strain was identical to strains isolated from raw milk of the regions where the cheese was produced. Therefore, it is probable that the contamination of milk with the propionibacteria causing brown spots in cheeses occurs not on the farm but in the cheese factory.

More intensive salting of cheeses could, according to some studies at the Federal Dairy Research Institute Switzerland, prevent the formation of brown spots. Nevertheless, it would be better to try and prevent contamination of milk with propionibacteria in the cheese factory.

\section{REFERENCES}

[1] Bachmann H.P., Isolini D., Prüfung von wilden Propionsäurebakterien-Stämmen im Emmentaler Modellkäse, Schweiz. Milchw. Forschung 24 (1995) 19-22.

[2] Baer A., Ryba I., Grand M., Ursachen der Entstehung von braunen Tupfen im Käse, Schweiz. Milchw. Forschung 22 (1993) 3-7.

[3] Costas M., Numerical analysis of sodium dodecyl sulphate-polyacrylamide gel electrophoretic protein patterns for the classification, identification and typing of medically important bacteria, Electrophoresis 11 (1990) 382-391.

[4] Costas M., Pot B., Vandamme P., Kersters K. Owen R.J., Hill L.R., Interlaboratory comparative study of the numerical analysis of onedimensional sodium dodecyl sulphate-polyacrylamide gel electrophoretic protein patterns of Campylobacter strains, Electrophoresis 11 (1990) 467-474 .

[5] Costas M., Holmes B., Ganner M., On S.L.W., Hoffman P.N., Worsley M.A., Panigrahi H., Identification of outbreak-associated and other strains of Clostridium difficile by numerical analysis of SDS-PAGE protein patterns, Epidemiol. Infect. 113 (1994) 1-12.

[6] Fessler D., Casey M.G., Puhan Z., Propionibacterial flora in Swiss raw milk from lowlands and Alps, Lait 79 (1999) 201-209.

[7] Hettinga D.H., Reinbold, G.W., Vedamuthu E.R. Split defect of Swiss cheese. I. Effect of strain of Propionibacterium and wrapping material, J. Milk Food Technol. 37 (1974) 322-328.

[8] Park H.S., Reinbold G.W., Hammond E.G., Role of propionibacteria in split defect of Swiss cheese, J. Dairy Sci. 50 (1967) 820-823.

[9] Park H.S., Reinbold G.W., Hammond E.G., Clark W.S., Growth of propionibacteria at low temperatures, J. Dairy Sci. 50 (1967) 589-591.

[10] Sollberger H., Einflussfaktoren auf das Verbalten von Propionsảurebakterien in Käse: Situationsanalyse zu Forschungsschwerpunkt 1996 der Sektion Käsetechnologie, Federal Dairy Research Institute, Switzerland, International report 11 (1996) 7-17.

[11] Steffen C., Vergleichende Untersuchungen in Emmentalerkäsen mit und ohne Nachgärung. Schweiz. Milchw, Forschung 8 (1979) $44-48$.

[12] Tsakalidou E., Manolopoulou E., Kabaraki E., Zoidou E., Pot B., Kersters K., Kalantzopoulos G., The combined use of whole-cell protein extracts for the identification (SDS-PAGE) and enzyme activity screening of lactic acid bacteria isolated from traditional Greek dairy products, Syst. Appl. Microbiol. 17 (1994) $444-448$.

[13] Zaugg E., Braune Tupfen im Halbhartkäse: harmlos aber unerwuinscht, Schweiz. Milchz. 121 (1995) 1-9. 